\title{
Geology and petroleum possibilities of St. Lawrence Island, Alaska, 1969
}

Ormiston, A.R., Fehlmann, R.H., and Amoco Oil Co.

GMC DATA REPORT 449

This GMC data report from the Amoco Heritage collection has been made available through funding from the FY2018 USGS National Geological and Geophysical Data Preservation Program, Grant Number G18AP00054. This project report is presented in its original format and has not been reviewed for technical content or for conformity to the editorial standards of DGGS. It should not be used or cited as reviewed data.

2019

State of Alaska

Department of Natural Resources

Division of Geological \& Geophysical Surveys

GEOLOGIC MATERIALS CENTER
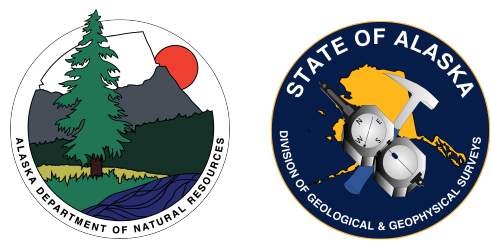


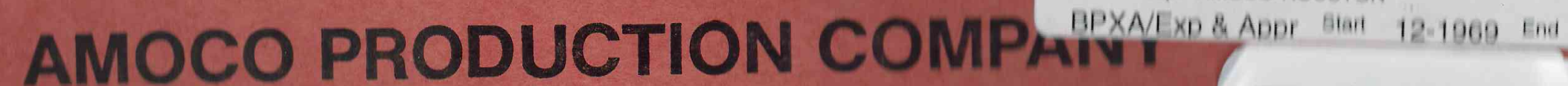

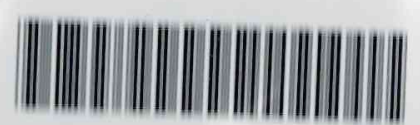 \\ GMC-000082538}


FORM $172 \quad 7-66$

FORM $1729-66$

PAN AMERICAN PETROLEUM CORPORATION

DIVISION Denver Division

TWP. OR SURVEY

AREA

St. Lawrence Is land

SUBJECT: Geology and Petroleum Possibilities

of St. Lawrence Island, Alaska

GEOLOGICAL Memorandum NO. 124

DATE December 11, 1969

ENCLOSURES:

PREPARED BY Allen R. Ormiston and

Robert Fehlmann

E.E. NO. (S) 


\section{Pan American Petroleum Corporation}



Mr. M. R. Waller

Tulsa, Oklahoma

Dear Sir:

Transmitted is the subject memorandum by Messrs. Allen R. onniston and Robert Fohlmann.

This study provides a basic stratigraphic fumaework for further evaluation of the petroleun potential of the Morton Basinmbering
sea complex.

Very truly yours,

Original Signod By

W. L. ADAMS

M. L. Adams

WLA:vh

cc: Mr. G. F. Stansberry

Mr. P. H. Garrison

John mikeerer 


\title{
Pan American Petroleum Corporation
}

SECURITY LIFE BUILDING

\author{
Denver, Colorado 80202
}

January 15, 1970

Re: Denver Division Geologica1

Memorandum No. 124

Geology and Petroleum

Possibilities of St. Lawrence

Island, Alaska

Mr.W. L. Adams

Building

Dear Sir:

Transmitted herewith is Denver Division Geological Memorandum No. 124, a study of the geological and petroleum possibilities of St. Lawrence Island, Alaska.

Based on information that $8500^{\prime}$ of Devonian thru Tertiary sediments are present on St. Lawrence Island, the Denver Division included work on the Island in the 1969 summer field program. It was felt a better understanding of this sedimentary sequence would aid in evaluating the petroleum possibilities of the Norton Basin and the Northern part of the Bering Sea.

The main objectives were to establish lithology, thickness, age and reservoir potential of each sedimentary unit on the Island. Igneous rocks were also collected for radioactive dating. All these objectives were met.

This memorandum is a joint effort of the Research Center and the Denver Division and sets forth the results obtained from the field data. Because of structural and facies complications it is difficult to project the Paleozoic and Mesozoic sequence offshore. However, we believe a non-marine to marine inter-tonguing may be present in the offshore to the north of the Island.

This work will serve as a valuable reference and provides us with some basic data, which we can hopefully build on in the future and ultimately gain a better understanding of the Geology of the Greater Bering Sea Area.

GFS / RNW/cdm

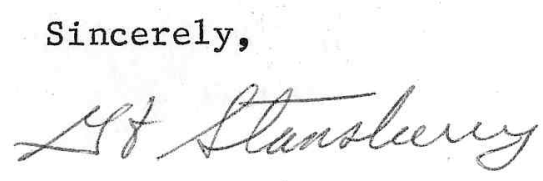

G. F. Stansberry 
Denver Division Geological

Memorandum No. 124

Geology and Petroleum Possibilities

of St. Lawrence Island, Alaska

Project No. 69-2

\section{INTRODUCTION}

The purpose of this memo is to present the stratigraphy, paleontology, and the petroleum potential of the Devonian through Tertiary section occurring on St. Lawrence Island, Alaska.

\section{CONCLUSIONS}

(1) The northern part of the Bering Sea is a potential petroleum province.

(2) From the St. Lawrence Island outcrops the following stratigraphic column can be inferred to underlie the Bering Sea: about 5000' of vuggy Devonian dolomites, 1500' of Meramec and possibly younger Mississippian Limestones, 350 to $400^{\prime}$ of Triassic shales, cherts and limestones, about 1000' of graywackes and mudstones of Jurassic and/or Cretaceous age, an undetermined thickness of predominantly continental Tertiary rocks with coals, and hundreds of feet of late Cenozoic volcanic flows.

(3) The vuggy, biostromal Devonian dolomites have some reservoir potential in themselves, and the facies present in the Devonian suggest the possible presence of true reefs in the subsurface.

(4) Although the Triassic of St. Lawrence is primarily shale, age equivalent rocks on nearby Chukotsky Peninsula are reported to include sandstones and conglomerates. Thus, a sand facies may exist in the Bering Sea subsurface north or northwest of St. Lawrence.

(5) The coal-bearing Tertiary sequence includes arkosic sandstone suggesting proximity to source at one locality of Miocene age, and a shallow-water marine transgression at another locality where the rocks are of Upper Oligocene age. This section is probably characterized by rapid lateral facies changes. The presence of a Tertiary basin (Norton Basin) to the north of St. Lawrence (Scholl and Hopkins, 1969) implies a northward facies change to marine rocks.

(6) The potential for significant stratigraphic traps exists in the subsurface Devonian, Triassic and Tertiary north of St. Lawrence Island.

\section{REFERENCES}

Armstrong, A. K., and Dutro, J. T., 1969, Carbonate Facies and Coral Zonation, Mississippian, Kogruk Formation, Lisburne Group, Delong Mountains, Brooks Range, Northwestern Alaska: A.A.P.G., Vol. 53, No. 3, P. 704.

Armstrong, A. K., Mamet, B. L., and Dutro, J. T., 1969, Foraminiferal Zonation and Carbonate facies of the Mississippian and Pennsylvanian Lisburne Group, Central and Eastern Brooks Range, Arctic Alaska: U.S.G.S. Open-file Report.

Gryc, G., 1968, Geological and Geophysical Investigations by the U.S.G.S. in Alaska in 1968, A.A.P.G., v. 53, no. 6, p. 1324-1325. 
Linsley, R. M., 1968, Gastropods of the Middle Devonian Anderdon Limestone: Bul1. American Paleont., vol. 54, no. 244, p. 333-445.

Markov, F. G., and Tkachenko, 1961, The Paleozoic of the Soviet Arctic, in Geology of the Arctic, vol. 1, p. 31-47.

Patton, W. W. and Dutro, J. T., 1969, Preliminary Report on the Paleozoic and Mesozoic Sedimentary Sequence on St. Lawrence Island, Alaska: U.S.G.S. Open-file report - 1969 .

Patton, W. W. and Tailleur, I. L., 1964, Geology of the Killik-Itkillik Region, Alaska, U.S.G.S. Prof. Paper 303-G.

Sachs, V. M. and Strelkov, S. A., 1961, Mesozoic and Cenozoic of the Soviet Arctic, Geology of the Arctic, v. 1, p. 48-67.

Scho11, D. W., Buffington, E. C., and Hopkins, D. M., 1968, Geologic history of the continental margin of N.A. in the Bering Sea, Marine Geol., v. 6 , p. 297-330.

Schol1, D. W. and Hopkins, D. M., 1969, New1y discovered Cenozoic Basins, Bering Sea shelf, Alaska: A.A.P.G., vol. 53, no. 10, p. 2067-2078.

Sutherland, P. K., 1958, Carboniferous Stratigraphy and Rugose coral faunas, northeastern B.C., G.S.C. Memoir 295 .

\section{FIGURES}

Figure 1 - St. Lawrence Island Measured Section Index Map。

Figure 2 - Devonian Section St. Lawrence Island, Alaska.

Figure 3 - Mississippian to Cretaceous Section St. Lawrence Island, Alaska.

\section{PLATES}

Plate 1 - Rock types and fauna of the Gastropodal Dolomite member, and lower part of the Gray and Buff Dolomite, Member, Seknak River Devonian Section, St. Lawrence Island.

P1ate 2 - Rock Types and Fauna of the upper part of the Gray and Buff Dolomite Member and the Dark Dolomite Member, Seknak River Devonian Section, St. Lawrence Island.

P1ate 3 - Fossils from Mississippian and Triassic Rocks, St. Lawrence Island.

Plate 4 - Field Photographs Showing Exposures of Devonian, Mississippian and Tertiary Rocks on St. Lawrence Island.

\section{DISCUSSION}

The discovery of fossiliferous Paleozoic rocks on St. Lawrence Island is recent (Patton and Dutro, 1969) and somewhat surprising considering the metamorphosed condition of rocks of this age on Seward Peninsula, which is the geographically nearest part of the Alaskan mainland. The exposures on St. Lawrence Island provide a unique glimpse of the stratigraphic section that must underlie the Bering Sea and are therefore especially important for the evaluation of the petroleum potential of a wide region covered by water. The presence of marine sedimentary rock of Paleozoic and Mesozoic ages on St. Lawrence Island, to the east of St. Lawrence Island on the Alaskan mainland, and also to the west of St. Lawrence Island on the Chukotsky Peninsula of Siberia (Markov and Tkachenko, 1961), requires the conclusion that at least the entire northern half of the Bering Sea (Bering Sea Shelf of Scholl \& Hopkins, 1969) functioned as a sedimentary basin throughout most of this time and accumulated the following succession: The Devonian rocks are a thick sequence of shallow water to 
lagoonal dolomites containing fossils suggestive of near-reef conditions and having fair porosity. They are much less altered than the correlative Baird Group of the Baird Mountains.

The $1500^{\prime}$ of Mississippian strata measured on the island can largely be assigned to the Meramecian Stage as indicated by megafossils and conodonts. This Meramecian sequence appears to rest unconformably on the Devonian.

Middle and Upper Triassic are represented by about 300 feet of shales and siltstones. These rocks are age equivalent to the Shublik Formation of the Brooks Range. No sandstones were seen but a sandstone facies of this age is developed in nearby Siberia (Markov \& Tkachenko, 1961).

Presumed Jurassic and/or Cretaceous rocks consist of graywackes and dark shales and closely resemble rocks of this age in the central Brooks-Range.

Coal-bearing terrestrial rocks of mid-Tertiary age are exposed at two widely separated localities on the island. Megaplants and palynology samples from this sequence are under study by D. W. Engelhardt of the Denver Division. The limited exposures of this Tertiary sequence include about $10^{\prime}$ of arkosic sandstones. These exposures probably represent a basin-edge facies of part of this thick (6,000') Tertiary sequence (Scholl and Hopkins, 1969) in the subsurface Norton Basin to the north.

The stratigraphic sequence is capped by a series of volcanic flows (at least eight) ranging in age from Pliocene to Recent (U.S.G.S. radiometric, dates, Patton, personal communication).

On the basis of stratigraphic studies of Devonian through Tertiary rocks conducted on St. Lawrence Island in 1969, much of the Bering Sea region must be considered a potential petroleum province. This stratigraphic judgement must of course be tempered by consideration of geophysical surveys of the Bering Sea area which could indicate a discouragingly large amount of past igneous activity. Sediments exposed on St. Lawrence Island have not, however, been metamorphosed and certain of them, especially those of Devonian age, show good reservoir potential.

\section{Field Procedure}

Two weeks of the 1969 field seas on were spent on St. Lawrence Island by R. Fehlmann of the Denver Division and A. Ormiston of the Research Center, during which time six major stratigraphic sections were measured and collected. Paleontologic study of this material carried out at the Research Center together with stratigraphic observations made in the field and subsequent polished slab and thin section studies are the basis of the interpretations in this report.

The geologic setting and structure are well discussed by Patton and Dutro (1969) to which the interested reader is referred. Localities mentioned in the text are shown on Figure 1.

\section{STRATIGRAPHY}

\section{Devonian}

The best Devonian exposures are along the Seknak River (Fig. 1, locality 8) where some 4,800 feet of beds were measured (see figure 2). Patton and Dutro (1969, p。5) reported a lesser thickness for these rocks apparently because they did not observe the basal gastropodal dolomite member (this report). 
Although not well preserved in these Devonian dolomites, fossils are not rare. Patton and Dutro (1969) recognized the presence of Amphipora, Thamnopora and Favosites. Pan American collections include numerous specimens of those three genera plus: abundant gastropods (beds $1,2,3,4,5$, $6,9,10,11,14,25$ and 35); brachiopods (beds 16, 27 and 35); tetracorals (beds 16 and 35 ), ostracodes (beds 25 and 26); laminar stromatoporoids (beds 14 and 26); button stromatoporoids (bed 26); and stromatolites (bed 3).

Certain of these fossils (e.g., stromatolites, Amphipora, abundant gastropods) have special environmental significance important to the interpretation of the rocks.

The Devonian of St. Lawrence Island is preponderantly dolomite with a few thin limestones and shales. The dolomites are conveniently divided into three members for which the following descriptive names are proposed (ascending order): (1) Gastropodal Dolomite Member (1200'), (2) Gray and Buff Dolomite Member (1500') and (3) Dark Dolomite Member $\left(2,100^{\prime}\right)$.

\section{Gastropoda1 Dolomite Member}

The abundance of gastropods (Plate $I$, fig. 1, 4) together with the rare presence of stromatolites (Plate 1 , fig. 2) suggests a shallow water slightly hypersaline environment of deposition. The local abundance of the typical reef-associate Amphipora (Plate 1, fig. 5) further suggests that this may have been a lagoon formed behind a reef or bank barrier. The gastropods present in this unit (Murchisonia, Mesocoelia, Mourlonia) resemble species present in the reef-associated Middle Devonian (Linsley 1968) Anderdon Limestone of Ohio and Michigan. Gastropods often are the locus for skelmoldic porosity developed (Plate 1 , fig. 1) in these rocks (Lab analysis of Seknak-1 shows effective porosity of 2.2 ).

\section{Gray and Buff Dolomite Member}

Gastropods still occur in this unit, but are not typical as in the underlying beds. A change in environment of deposition to shallow waters of more nearly normal salinity in which biostromal organic associations developed is suggested by the appearance of recognizable massive stromatoporoids, tetracorals, ostracodes, and brachiopods. Dolomitization has altered organic fabrics to such an extent that positive recognition of what appear once to have been stromatoporoids (e.g., in Seknak-16) is not always possible. Often all that remains of what probably once were stromatoporoids is an "organic" look to the rock texture (See Plate 1, fig. 9). The original abundance of stromatoporoids in this unit may, therefore, have been considerably greater than now recognized.

Al1 other fossils have also been greatly altered by dolomitization but not to. the extent that they are unrecognizable. Skelmoldic porosity is well developed in tetracorals, ostracodes and Amphipora (Plate 1, fig. 5).

The appearance of tetracorals (Plate 1, figs. 6, 7, 8) and brachiopods (P1ate 1, fig. 7 lower right) is sound evidence for the prevalence of near normal salinities and suggests a more open marine environment than that of the underlying Gastropodal Dolomite Member. These beds may have been biostromal carbonates. The presence of algal? coats around ostracodes in some of these dolomites (P1ate 2, fig. 12) suggests a quite shallow, well-lighted and probably wave-agitated environment.

Elongate, white crystals of tetragonal cross section are abundant in many of the dolomites of this unit. The original mineralogy of these crystals is unclear as they have now been pseudomorphous ly replaced by "a mixture of chlorite, kaolinite and montmorillonite. Neither the crystal habit nor the chemical replacement seems right for an original evaporitic mineral such as a sulfate. Possibly the original mineral was a silicate such as wollastonite produced by epithermal alteration of the host dolomites. 
Two dark limestones within this unit (Seknak 20-15' above base, and Seknak-21) were processed for conodonts but proved barren.

Other fossils suggest a late Middle Devonian age for this unit.

\section{Dark Dolomite Member}

Dark gray to black dolomites with some black shale beds are the dominant lithologies. One of these shales (Seknak-32) has been run for palynomorphs but proved barren. The dolomites are characterized by an abundance of tabulates (primarily Thamnopora but also Favosites) and stromatoporoids (see Plate 2, figs. $8,9,12$ ). Bitumen is seen in several of the beds in this member and the impression in the field was that certain of these dolomites had good source-rock potential. This impression is not borne out by sourcerock examination of Seknak-28, 30, and 32 carried out at the lab. Seknak-32 which contains sooty bitumen did, however, show good porosity (15.9\%) and permeability ( 8.94 millidarcies).

Although organisms (see appendix) are still reasonably abundant, there is far less total rock footage exhibiting associations of potential frame builders than there is in the underlying member. The presence of some fine clastic sediments suggests a slightly deeper environment of deposition than prevailed for the underlying rocks. A shelf rather than a basinal environment is still required by the coral types present, however.

The fossil assemblage suggests either a later Middle Devonian or early Upper Devonian age for this unit.

\section{$\underline{\text { Remarks }}$}

The Devonian section is preponderantly dolomite, is thick and is divisible into three discrete members each interpreted as having had a different environment of deposition. The lowest member is apparent1y a 1agoonal deposit generated behind a barrier, probably reefal. The middle member contains organic associations of stromatoporoids and other fossils and is considered to be partly biostromal in origin. The upper member is considered a slightly deeper water, but still shelf, deposit.

These rocks have been labeled reef dolomites by Gryc (1968, p. 1324), but this is true only in the broadest sense. No true reefs (wave resistant organic structures rising above the level of the neighboring sea floor) are present. The lagoonal Gastropodal Dolomite Member is, however, probably reef-associated, and the overlying biostromal Gray and Buff Dolomite Member has organic rocks with good skelmoldic porosity.

What is important in evaluating these rocks as potential reservoirs is that a lagoonal deposit suggests the nearby presence of reefs and that a thick enough biostromal rock with good skelmoldic porosity can also be a reservoir.

The contained fossils (see appendix) indicate that part of this section is late Middle Devonian (Givetian) in age and that the upper member may be as young as early Upper Devonian (Frasnian). These strata are thus time equivalent to the Skajit Formation of the mainland.

\section{Mississippian}

The Devonian-Mississippian contact is apparently disconformable as can be seen in a small tributary to the east fork of Ongoveyuk River (figure 1 , locality 6) where a small amount of relief is visible between dolomitic limestones of Mississippian age and underlying laminated dolomites resembling certain beds of the Seknak River section (figure 1, locality 8). 
The division of the St. Lawrence Mississippian limestones into a lower darkcolored, cherty member and an upper light-colored thicker-bedded member as recognized by Patton and Dutro (1969, p. 6) is substantiated by our field work (see figure 3). We assign a greater thickness (800') of rock to the upper member than did Patton and Dutro apparently because of a different placement of the member boundary in the ONGO-W section (Locality 4188). We would place this boundary no higher than ONGO-W-8.

Conodont and megafossil studies show that the oldest exposed Mississippian on St. Lawrence is Meramecian in age. In fact, all but the upper 160 feet of the upper member is Meramec. The upper 160 feet has yielded conodonts, which are insufficiently diagnostic to decide between Meramec and Chester. The possibility thus exists that this uppermost $160^{\prime}$ interval could be of Chester age.

The Mississippian rocks are fossiliferous throughout and all major groups appear to be represented. Paleontologic studies have been carried out by thin section, acidization for conodonts and silicified brachiopods and handtooling techniques to free individual specimens. Some of the more typical and/or diagnostic elements are illustrated on Plate 3. Of particular importance is the presence of an association of the brachiopod Gigantoproductus and the coral Lithostrotione1la (Plate 3, figures 2-4); ONGO-W-17. The same two forms are found together in the upper part of the Alapah Limestone of the central Brooks range (Bowsher and Dutro, 1957). The same species of Lithostrotionella is also reported by Armstrong and Dutro (1969) from the upper Shogruk Formation of the Delong Mountains, which is therefore also of Meramec age. Conodonts recovered from St. Lawrence Island (see Appendix, H. R. Lane) show that this horizon is of upper St. Louis age in terms of the Mississippian Valley standard.

The presence in the lower unit of forms such as dasyclad algae (Plate 3, fig. 5) and abundant bryozoans (Plate 3, fig. 1) shows that the unit, despite its dark color and argillaceous content, was a shallow water deposit. Detrital influx probably was intermittent during the deposition of this unit so that there were periods during which such delicate bottom-dwellers could thrive. Corals are abundant throughout the St. Lawrence Mississippian, several of the more common types are illustrated on Plate 3 (Figures 8-10, 12, 14, 15). Endothyrid foraminifera of zonal value have been recognized by Mamet (personal communication, W. Patton) from several levels in the St. Lawrence Mississippian. Examination of about 40 thin sections made from Pan American collections has revealed endothyrids at only two levels (see Plate 3, fig. 13), those being ONGO-W-12 and ONGO-W-17.

The upper member in addition to having a varied fauna (brachiopods, trilobites, bryozoans, corals, endothyrids) consist largely of grainstones and is clearly a product of a shallow water agitated environment.

In addition to the fairly continuous exposures of the upper member along the west fork of the Ongoveyuk River and of the lower member along the east fork of the Ongoveyuk River there are scattered exposures of Mississippian rocks elsewhere on St. Lawrence Island as, for example, along the shore of Niykhapakhit Lake where calcarenites are exposed in rubble patches. No megafossils were seen at that locality, but bulk rock collected there has yielded conodonts of Meramec age (see Appendix, H. R. Lane). Such scattered outcrops suggest that much of the eastern part of the island is underlain by Mississippian rocks that are for the most part poorly exposed.

\section{$\underline{\text { Remarks }}$}

The Mississippian consists of about 1500' of shallow water shelf carbonates containing a varied fossil fauna, none of which is older than Meramec in age. The absence of pre-Meramec Mississippian rocks here indicates that the Mississippian system in northern Alaska loses section at its base as one progresses both east and west from the central Brooks Range (e.g., Shanin Lake area) which is the only region where older Mississippian carbonates are known. The Gigantoproductus bed of the upper member is correlative with part of the Alapah Limestone of the central Brooks range. Whether or not part of the uppermost $160^{\prime}$ of Mississippian rocks on St. Lawrence Island is of Chester age cannot be determined at this time. 







\section{UNDATED INTERVAL}

There are about 50 feet of beds consisting of cherts, siltstone and shale samples (ONGO-W-27-29 which conformably (?) overlie the Mississippian and underlie known Triassic rocks in the section at locality 5 (figure 1). Although searched for, no fossils were found in these beds. There is a possibility that these beds are of Permian age (i.e., are a Siksikpuk equivalent). The only chance of demonstrating the age of this interval depends on recovering palynomorphs from the shales. Samples so far processed from this interval (D. W. Engelhardt) have proved barren.

\section{TRIASSIC}

Between 350 and 400 feet of dark shales, dark limestones, and siltstones conformably overlie the undated interval (locality 5, figure 1) and contain fossils of Middle and Upper Triassic age. At the time of our visit about 75 feet in the middle of this section was buried by drifted snow and could not be directly examined. Float fossils almost certainly coming from this interval were collected in the stream bed and prove to include the clam Daonella cf. frami (see Plate 3, fig. 16) of Middle Triassic age. Samples from higher in this section (samples ONGO-W-35, 36, 37, 38) have yielded palynomorphs which are indicative of an Upper Triassic age, (H. J. Sullivan, personal communication). To judge from the contained fossils these are not deep-water shales.

These Triassic strata are closely comparable to the upper part of the Shublik Formation of the Brooks Range both 1ithologically and faunally.

Another Triassic exposure on the south shore of Tomname Lagoon (10 miles SW locality 9, figure 1) was briefly examined but consists only of dark shale rubble with no obvious fossils.

In the USGS collections at Menlo Park I have seen blocks of cherty limestone with Monotis (this upper Triassic clam also occurs in a similar lithology in the Shublik of the Brooks Range) which were collected as float on the northwestern part of St. Lawrence Island. No bedrock outcrops of Triassic have been demonstrated in this area, but no detailed geology has yet been done there.

\section{Remarks}

There is marked similarity in lithology and faunal content (and presumably, tberefore, in environment of deposition) between the St. Lawrence Triassic and the upper part of the Triassic of the Brooks Range of the mainland. Triassic float on the northwest part of the island suggests a possible wider distribution of Triassic on the is land than now demonstratid.

No sandstones were seen in the St. Lawrence Island Triassic, but Traissic rocks of this age on Chutkotsky Peninsula, Siberia (about 50 miles to the west) contain sandstone and conglomerates (Sachs and Strelkov, 1961, p. 49, and figure 1). Thus the sorts of Triassic facies changes which occur on the North Slope, (Patton and Tailleur, 1964, p. 435) can probably also be expected in the subsurface to the north and/or northwest of St. Lawrence Island.

\section{JURASSTC AND/OR CRETACEOUS}

Along the main course of the west fork of the Ongoveyuk River (figure 1, locality 4) there are exposures of graywackes and shales which are lithologically similar to rocks of Jurassic and/or Cretaceous age on the North Slope (e.g., in the Utukok River section). No diagnostic fossils have been recovered but these beds overlie the Triassic. Local structural complications make an accurate thickness determination difficult, but a continuous measured section shows the minimum thickness to be 750 feet. The true thickness is probably much greater. These beds occupy a fairly wide outcrop belt and appear to dip northward beneath volcanic rocks of presumed Tertiary age. 
These strata show features (e.g., sole markings and graded bedding) typical of turbidite deposits, suggesting they were deposited in a deeper water environment than the older rocks previously discussed.

Submarine acoustic profiles show that this Mesozoic sequence (Scholl and Hopkins, 1969) forms the acoustic basement which is overlain unconformably by a thick Tertiary section.

\section{TERTIARY}

Outcrops of Tertiary sediments are scattered and incomplete. The two best exposures are on the west shore of Niyrakpak Lagoon (figure 1, locality 1) and on the Fossil River (figure 1, locality 3). The first locality exposes about 50 feet of beds and the second about 15 feet. Both localities include coals and abundant plant remains and the primary environment of deposition is clearly continental. However, the presence of the tidal-flat pecten Propeamussium somewhere in the Fossil River section (see Research Department Memorandum, December 10, 1968) is evidence that at least one sha1low-water transgression is represented in this Tertiary section. We were unable to duplicate the Propeamussium collection in the short Tertiary section examined on the Fossil River.

The thicker section that is exposed on the west shore of Niyrakpak Lagoon includes besides coals, siltstones and shales, about 10 feet of arkosic conglomerate and sandstone. These sandstones varied from well to poorly indurated, the variation apparently being the result of local leaching by meltwater.

Samples collected for palynology from both of these sections have been submitted to D. W. Engelhardt of the Denver Divison. The preliminary results of his examination suggest (personal communication) an Upper Oligocene age for the beds on Fossil River and a Miocene age for those at Niyrakpak Lagoon. The non-equivalence of the two exposures means they can be combined to form. a composite Tertiary section spanning the Oligocene-Miocene boundary.

These terrestrial rocks apparently represent a basin edge-facies of part of the thick (up to $6000^{\prime}$ ) Tertiary sequence filling the Norton Basin (Scholl and Hopkins, 1969, p. 2076) north of St. Lawrence, the younger Tertiary part of which, at least, is 1ikely to be marine (Scholl and Hopkins, 1969. p. 2077).

There are other scattered outcrops of what are probably Tertiary sediments elsewhere on eastern St. Lawrence Island. One such, is at Lake Kapsukalik (figure 1, locality 2) where flinty, white mudstones (probably altered by volcanic emanations from nearby Kookooligit Mountain) form a conspicuous patch of light colored rubble. No fossils were seen at this locality.

Exposures of acidic volcanics along the Fossil River probably are interbedded with the Tertiary sediments but the exposures are too poor to demonstrate concordant relations. Our impression, however, is that there are substantial amounts of volcanic rocks in the Tertiary succession of St. Lawrence Island. This could be tested by radiometric dating of volcanics (sample Fossil River-1) sampled along Fossil River.

There is no reliable means of estimating the thickness of the St. Lawrence Tertiary. It must considerably exceed the minimum of 65 feet that we were able to directly measure.

\section{CENOZOIC VOLCANICS}

Kookooligit Mountain and Taphook Mountain were centers of volcanic extrusion from the Pliocene to Recent. The sea cliff exposures along the north side of Kookooligit Mountain reveal a succession of at least eight separate flows, each with columnar jointing of the layer representing the top of the flow surface. These flows have been radiometrically dated (W. W. Patton, personal communication) as Pliocene (oldest flow) through Recent. This flow succession correlates with a similar sequence on Nunivak Island which is now being studied by the U.S.G.S。 


\section{CRETACEOUS INTRUSIVES}

Intrusive rocks generally of granodioritic composition are widely distributed on the island (e.g.,Tomname Mountain, Gambell Mountain, etc.) . These have been radiometrically dated as Cretaceous according to the U.S.G.S. Locally they have altered the sedimentary host rocks (see below).

\section{METAMORPHICS AT SOOGHMEGHAT POINT}

At Sooghmeghat Point (figure 1, locality 9) there is a seacoast exposure of about 20 feet of banded hornfels and limestone (see Plate 4, figure 3). These slightly metamorphosed beds are unlike any Paleozoics seen elsewhere on the island. Their original composition was probably that of an argillaceous limestone which is such a common rock type that any age is possible. They were apparently contact metamorphosed by the nearby Cretaceous intrusive that forms Tomname Mountain. Their age must, therefore, be pre-Tertiary. An attempt to recover conodonts from the limestone stringers in the rock was unsuccessful.

Al1en R. Ormiston

Robert Fehlmann

$\mathrm{ARO} / \mathrm{RF} / \mathrm{cdm}$ 


\section{APPENDIX}

1. Devonian Fossils from Seknak River Section St. Lawrence Island. Locality 4187. (2 pages)

2. Fauna1 List (Excluding Conodonts) Tributary to West Fork of Ongoveyuk River. Locality 4188. (1 page)

3. Fauna1 List (Excluding Conodonts) East Fork of Ongoveyuk River. Locality 4202. (1 page)

4. Conodont Identifications - Lower Member of the Mississippian on East Fork of the Ongoveyuk River, St. Lawrence Island. Locality 4202. (1 page)

5. Conodont Identifications - Upper Member of the Mississippian on West Fork of Ongoveyuk River, St. Lawrence Island. Locality 4188. (2 pages) 
Devonian Fossils from Seknak River Section,

St. Lawrence Island (Locality 4187)

Samp1e No.

Fossils

Seknak-1

Murchisonia sp. A

Seknak-2

"Mourlonia" sp.; indet. high-spired gastropod

Seknak-3

Murchisonia sp. A; stromatolites; indet. brachiopod

Seknak-4

Mesocoelia sp.; Murchisonia sp. A; Murchisonia sp. B; Amphipora sp.; indet. idiostrom

Seknak-5 indet. gastropods

Seknak-6 Murchisonia sp.

Seknak-7 fossils present but unidentifiable

Seknak-8

Seknak-9 Amphipora sp.; Mesocoelia sp.; trochoid gastropods

Seknak-10 "Murchisonia" sp.

Seknak-11 Murchisonia sp.

Seknak-12 --

Seknak-13 --

Seknak-14 Amphipora sp. (abundant); indet. gastropods, laminar stromatoporoids (abundant)

Seknak-15

Seknak-16 Cystiphylloides sp.; pentamerid brachiopod cf. Gypidula indet. brachiopod; ostracod; stromatoporoids??

Seknak-17

Seknak-18 indet. stromatoporoids?? 
Seknak-19 indet. stromatoporoids

Seknak-20 barren of conodonts

Seknak-21 barren of conodonts; no crinoids as stated in field notes

Seknak-22 --

Seknak-23 --

Seknak-24

Seknak-25 ostracods (abundant); Amphipora sp., indet. gastropods

Seknak-26 laminar stromatoporoids (abundant)

Seknak-26+80' button stromatoporoids

Seknak-27+100' ostracods (abundant); stromatoporoids

Seknak-27 Amphipora sp.; Thamnopora sp. (abundant); Favosites sp.; Cystiphylloides sp.; indet. idiostroms; brachiopods (Atrypa?)

Seknak-28

Seknak-29 Amphipora?

Seknak-30 barren of conodonts

Seknak-31 --

Seknak-32 --

Seknak-33 Amphipora?

Seknak-34 Seknak-35 Mesocoelia sp.; Emanuella sp•; Amphipora sp•; Favosites sp•;

Seknak-36

Seknak-37 Thamnopora sp. (abundant); Favosites sp.; tetracoral indet.; stromatoporoids 
Faunal List (Excluding Conodonts)

Tributary to West Fork of Ongoveyuk River

Locality 4188

ONGO-W-4

ONGO-W-8

ONGO-W-12

ONGO-W-16

ONGO-W-17

ONGO-W-18

ONGO-W-19

ONGO-W-20

ONGO-W-25

ONGO-W-34

ONGO-W-35

ONGO-W-36

ONGO-W-37

ONGO-W-38
Amplexizaphrentis? sp., Rhipidomella

Amplexizaphrentis sp.C

Amplexizaphrentis sp., Amygdalophyllum sp., endothyrid indet.

Amplexizaphrentis sp. C, Ekvasophyllum sp. A, Vesiculophyllum?, Fenestella sp., unidentified trepostome, Spirifer cf. tenuicostatus, Rhynchopora sp., Orbiculoidia sp., Werria sp.

Gigantoproductus cf. striatosulcatus, chonetid, Lithostrotione11a aff. L. mclareni, Endothyra sp.

Ekvasophyllum sp. A, Paladin sp., Amphissites sp.

Ekvasophyllum sp. A, Amplexizaphrentis sp., productid indet.

Spirifer cf. tenuicostatus, Vesiculophy1lum? sp., productid indet.

Amplexizaphrentis sp. C, Ekvasophy1lum sp. A

Daonella cf. frami

Upper Triassic palynomorphs

Upper Triassic palynomorphs

Upper Triassic palynomorphs

Upper Triassic palynomorphs 
Fauna1 List (Excluding Conodonts)

East Fork of Ongoveyuk River

Locality 4202

\author{
ONGO-E-TRIB-6 dasyclad alga; indet. bryozoan \\ ONGO-E-TRIB-9 Amplexizaphrentis cf. sp. C Sutherland \\ Composita sp. \\ Echinoconchus sp. \\ Anthracospirifer? sp. \\ Rhipidomella sp. \\ Fenestella sp. \\ Sulcoretopora sp. \\ Spathognathodus scitulus \\ ONGO-E-TRIB-3 Spirifer cf. grimesi \\ Unispirifer aff. 2320 \\ Dictyoclostus sp. \\ Rugosochonetes sp. \\ ONGO-E-1 Syringopora sp. \\ ONGO-E-3 Rugosochonetes n. sp. \\ Sulcoretopora sp. \\ ONGO-E-4 Rugosochonetes n. sp. \\ ONGO-E-6 Amplexizaphrentis sp.
}




\section{CONODONT IDENTIFICATIONS}

Lower Member of the Mississippian on East Fork of the Ongoveyulk River, St. Lawrence Island. Locality 4202

Identifications by $H$. R. Lane

The occurrence of Spathognathodus 2727 in sample 5 indicates an upper St. Louis (upper Meramec) age. Sample 7 is Meramec or lower Chester.

\begin{tabular}{|c|c|c|c|c|}
\hline Sample No. & Footage & IBM No. & Identification & Count \\
\hline 5 & ONGO-E-TRIB-9 & $\begin{array}{l}2727 \\
2618\end{array}$ & $\frac{\text { Spathognathodus scitulus }}{\text { Indet. conodont }}$ & $\begin{array}{l}1 \\
1\end{array}$ \\
\hline 7 & ONGO-E-TRIB-3 & $\begin{array}{l}4489 \\
2618\end{array}$ & $\frac{\text { Magnilaterella }}{\text { Indet. conodonts }}$. & $\begin{array}{r}1 \\
21\end{array}$ \\
\hline 12 & $O N G O-E-3$ & & Spatho. sp. & \\
\hline
\end{tabular}

The presence of Spathognathodus $2727 \frac{\text { Sp. }}{\text { in }}$ sample 5 indicates an upper St. Louis (upper Meramec) age. Magnilaterella sp. occurs in sample 7 and indicates a Meramec or lower Chester age.

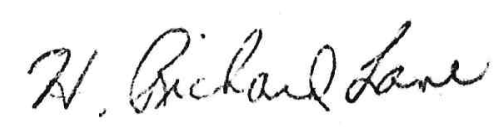

H. Richard Lane

HRL: sd 


\section{CONODONT IDENTIETCATIONS}

Upper Member of the Mississippian on West Fork of Ongoveyuk River, St. Lawrence

Island. Locality 4188

Identifications by H. R. Lane

Samples 13-20 indicate an upper St. Louis (upper Meramec) age. Samples 21-28 are upper Meramec or lower Chester in age. No determination can be made for sample 30 .

The following is a listing of samples processed:




$-5=$

contd.

Sample No. Footage IBM No. Identification

20

2740
2727
2618

Spathognathodus n. sp.

1.

Spathognathodus scitulus 1

Indet. conodonts

The occurrence of Apatognathus? 4507, A.? 2869, Spathognathodus

2727, and Ozarkodina 2846 in samples 13-20 indicates an upper St.

Louis (Meramec) (see Rexroad \& Collinson, 1963, p.6) age for the interval.

21

$\begin{array}{lll}\text { Ongo-W-20 } & 2740 \quad \frac{\text { Spathognathodus }}{n} \cdot \text { sp. } \\ & 2743 \quad \frac{\text { Spathognathodus }}{\text { homopunctatus }}\end{array}$

2845

ozarkodina

2618

Indet. conodonts

1

1

22

$\begin{array}{cr}\text { Ongo-W-20A } & 2740 \\ & 2618 \\ & \\ \text { Ongo-W-25 } & 2812 \\ & 2726 \\ & 2618\end{array}$

Spathognathodus n. sp.

Indet. conodonts

1

28

2812

Gnathodus texanus

Spathognathodus sp.

Indet. conodonts

The occurrence of Spathognathodus 2743, S. 2740, and Gnathodus 2742 in samples $21-28$ indicates upper Meramec (upper st. Louis) through Lower Chester age for the interval.

$$
\text { Ongo-W-27 } 2618 \quad \text { Indet. conodonts }
$$

The fauna is too inadequate to date sample 30 .

\section{REFERENCE}

REXROAD, C. B. \& COLLINSON, CHARLES, 1963, Conodonts from the St. Louis Formation (Valmeyeran Series) of Illinois, Indiana, and Missouri: I11. Geol. Survey Circ. 355, 28 p., 2 pls., 5 text-figs.

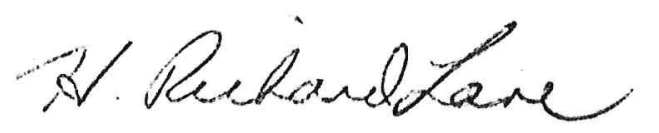

H. Richard Lane

HRL : sd 


\section{PLATE 1}

Rock types and fauna of the Gastropodal Dolomite Member, and lower part of the Gray and Buff Dolomite Member, Seknak River Devonian section, St. Lawrence Island.

Figure

1 Seknak-1, polished slab of gastropodal dolomite with skelmoldic porosity, X2.

2 Seknak-3, polished slab of stromatolitic dark dolomite, X2.

3 Seknak-4, polished slab of gastropod and Amphipora-bearing dolomite, X2.

4 Seknak-9, polished slab of richly gastropoda1, dark dolomite, X2.

5 Seknak-14, polished slab showing abundant, bedded Amphipora in which skelmoldic porosity is developed, X2.

6. Seknak-16, unprepared rock surface of dolomite with skelmoldic porosity developed in the tetracoral Cystiphylloides sp., X2.

7 Seknak-16, thin section (trans.) of Cystiphylloides and brachiopod (lower right), X5.

8 Seknak-16, thin section (1ong.) of Cystiphylloides, abundant at this horizon, $\mathrm{X} 5$.

9 Seknak-17, polished slab of ribbon-banded dolomite whose texture is probably derived from replaced stromatoporoids, X2.

Seknak-25, polished slab of a richly ostracodal dolomite, X2.

11 Seknak-26-100', thin section of ostracodal dolomite showing abundance of valves, X10.
Seknak-26-100', polished slab showing ostracodes overgrown by oncolites?. 

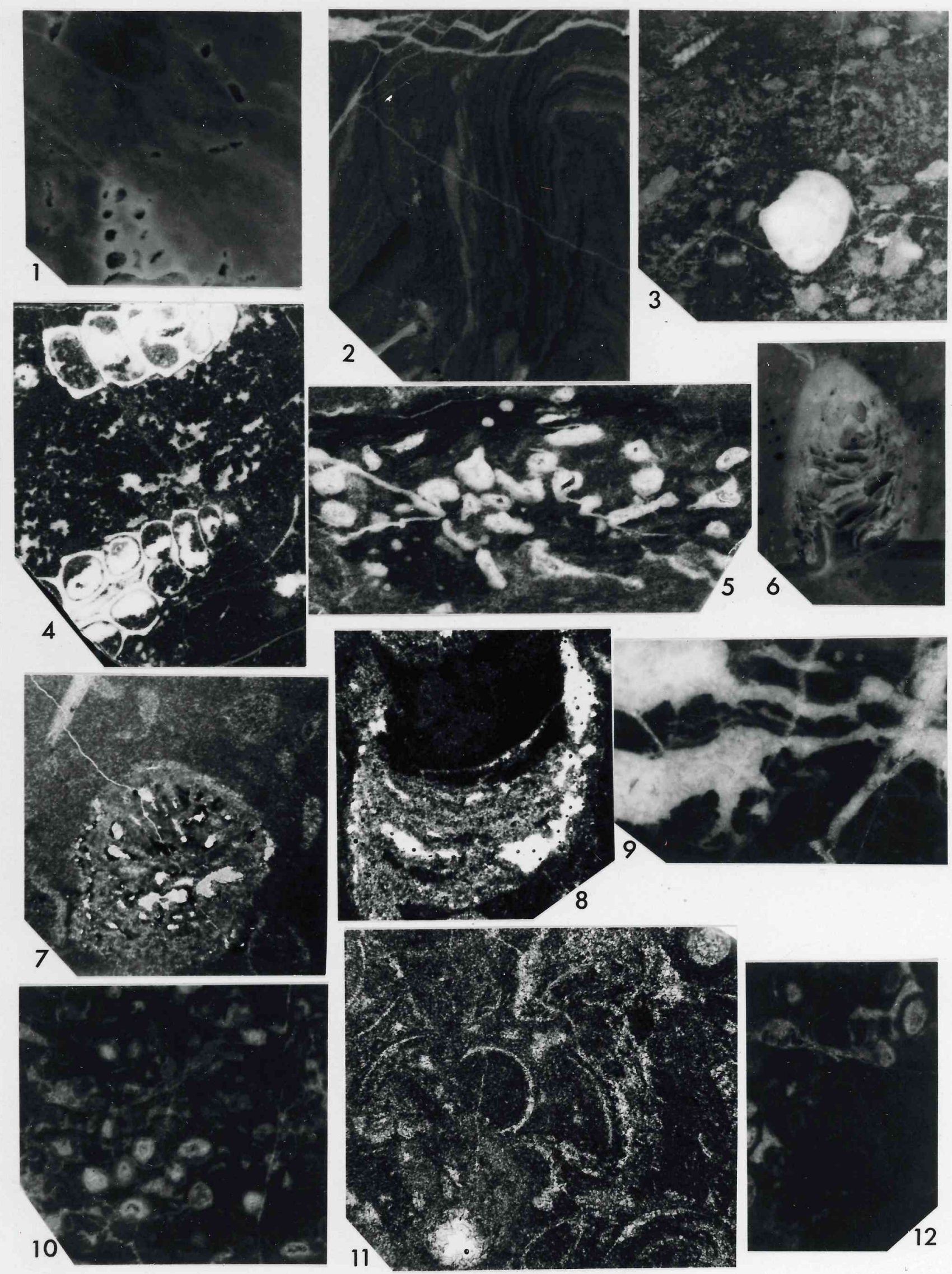
PLATE 2

Rock types and fauna of the upper part of the Gray and Buff Dolomite Member and the Dark Dolomite Member, Seknak River Devonian section, St. Lawrence Island.

Figure

Seknak-26, polished slab of laminar stromatoporoid rock, X2.

Seknak-26-80" up, polished slab of "button" stromatoporoid rock (boundstone), $\mathrm{X} 2$.

3 Seknak-27, polished slab of dark dolomite with abundant Thamnopora sp. (tabulate coral), X2.

Seknak-27, polished slab of Thamnopora and Amphipora-bearing dolomite with skelmoldic porosity in Thamnopora, X2.

Seknak-27, polished slab showing (top to bottom) brachiopod, Thamnopora and Cystiphy1loides, X2.

Seknak-27, polished slab of Thamnopora boundstone, X2.

Seknak-35, polished slab of brachiopodal dolomite, transverse section of valve in upper right is Emanuella sp., X2.

Seknak-37, thin section of stromatoporoid boundstone with indeterminate tetracorals, $\mathrm{X} 5$.

Seknak-35, thin section of boundstone with Favosites sp., in which there is skelmoldic porosity, $\mathrm{X} 5$.

10 Seknak-35, polished slab of brachiopodal dolomite in which various1y oriented sections of Emanuella sp. are seen, X2. $\mathrm{X} 2$. 


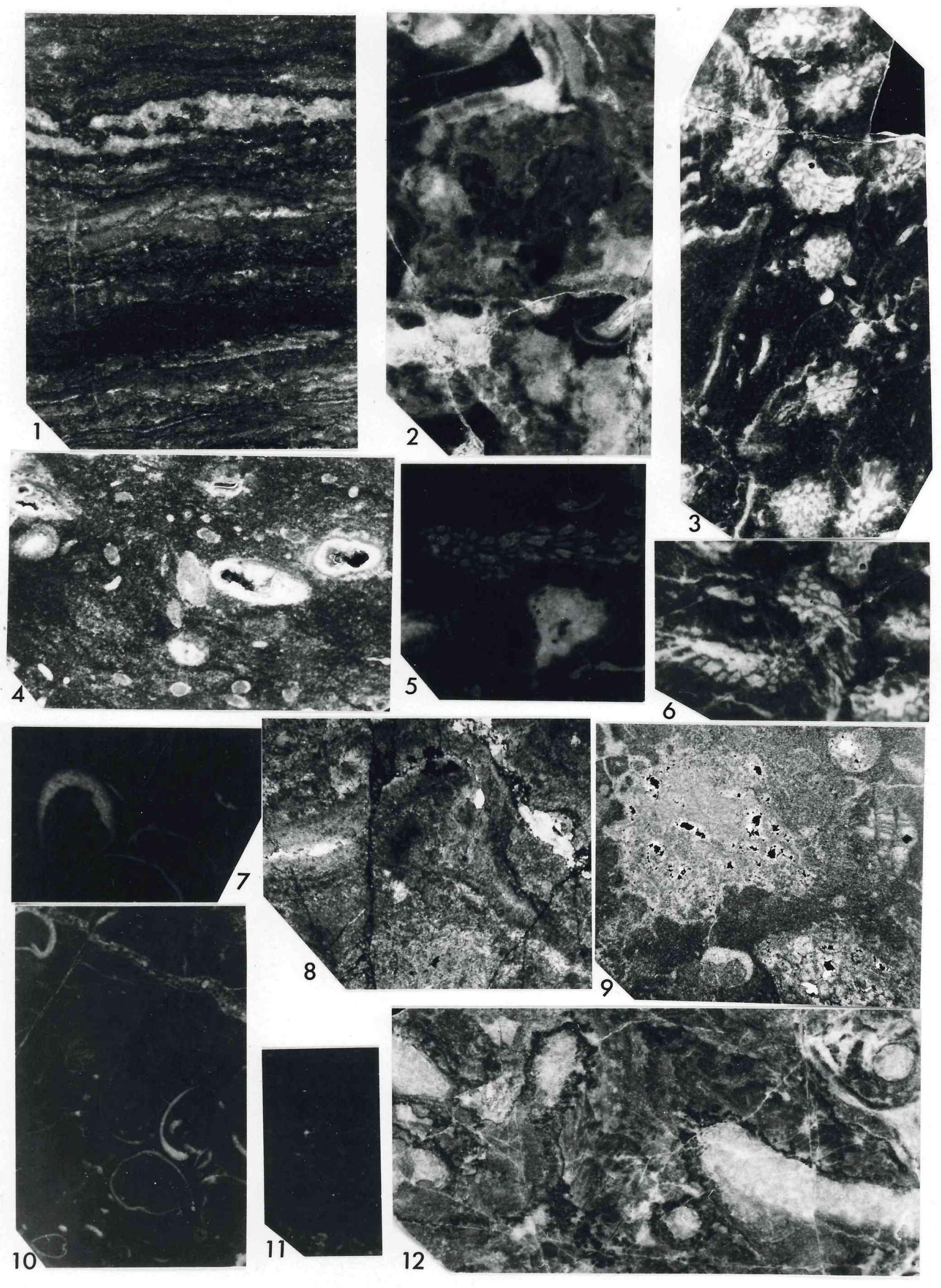


PLATE 3

Fossils from Mississippian and Triassic Rocks,

St. Lawrence Island

Figure

1 Rock slab from lower member showing (top to bottom) Echinoconchus, Fenestella and Sulcoretopora - Locality 4202-5, X0.5.

2, 3 Gigantoproductus cf. striatosulcatus, dorsal and latera1 views - Locality 4188-18, X0.5.

4 Lithostrotionella aff. L. mclareni, transverse section, Locality 4188-18, X2.

5 Cherty argillaceous limestone from lower member with dasyclad alga (upper left) and bryozoan, Locality 4202-2, X2.

6 Thin section of fenestellid-rich argillaceous limestone from lower member (see figure 1 of this plate) Locality 4202-5, X1.

7 Unidentified encrusting bryozoan - Locality 4202-5, X5.

8 Amplexizaphrentis sp., transverse section of ephebic stage - rock is oolitic and oolites are visible between the septa - Locality 4188-20, X5.

9 Ekvasophyllum sp. A, transverse section of ephebic stage - Locality 4188-20.

10,15 "Amygdalophy11um" n. sp., transverse and tangentia1 sections, XI and X5 respectively - Locality 4188-13.

11 Fossiliferous calcarenite with large productids, Locality 4188-21, X5.

12 Amplexizaphrentis cf. sp. C Sutherland, 1958, transverse section - Locality 4188-28, X1.

13 Endothyra sp., random section from oolitic rock of Gigantoproductus bed, Locality 4188-18, X20.

14 Ekvasophyllum sp., transverse section of adult specimen, Locality 4188-13, X1.

16 Daonella cf. frami, on bedding plane, middle Triassic, Locality 4188-37, X1. 


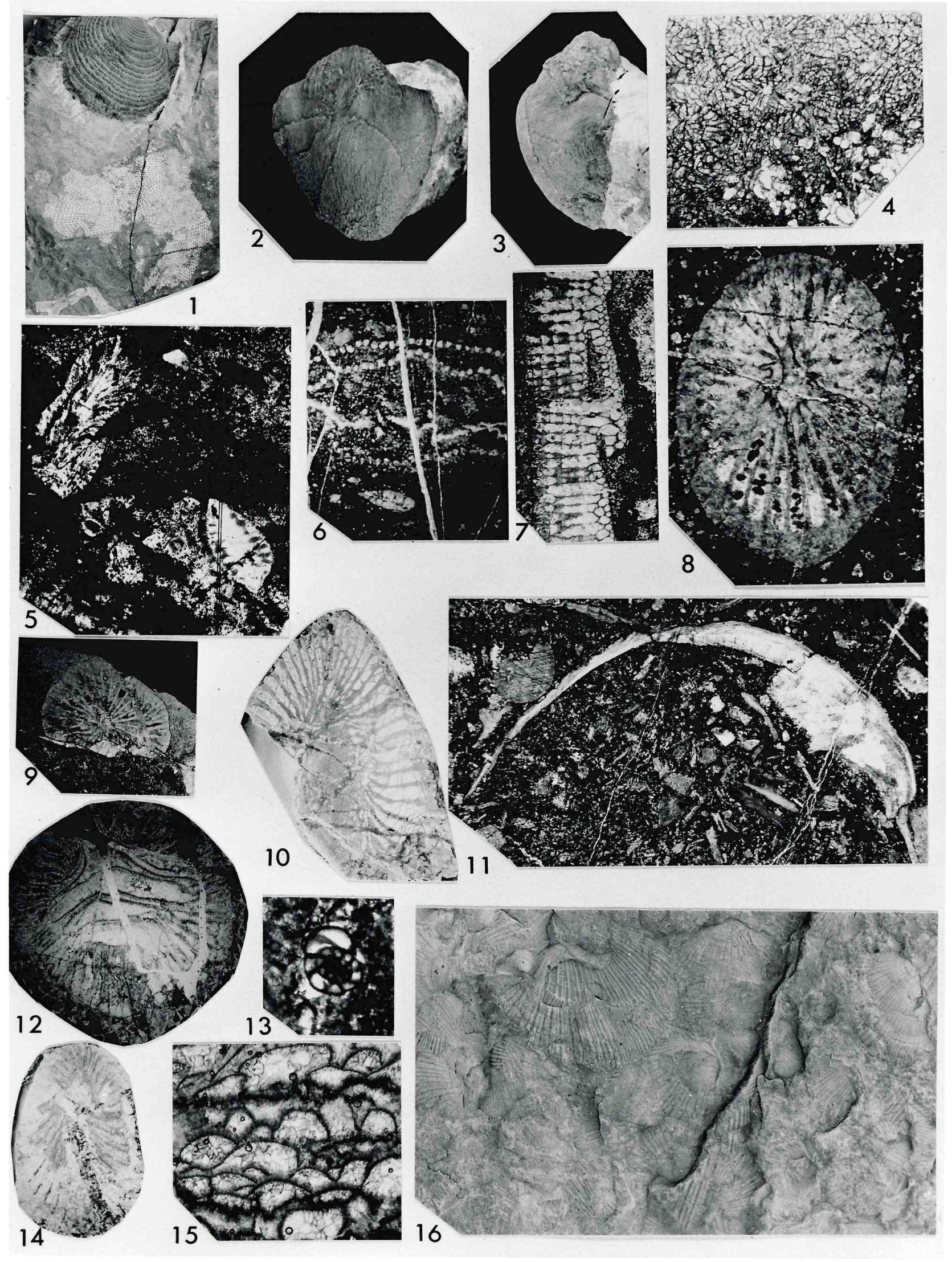




\section{PLATE 4}

Field Photographs Showing Exposures of Devonian, Mississippian and Tertiary Rocks on St. Lawrence, Island

\section{Figure}

Sekank-17, prominent outcrop of vuggy dolomites of Devonian age belonging to the Buff and Gray Dolomite Member of the Seknak River section, (Loc. 4187) photo by R. Fehlmann.

Low altitude view of exposures of the upper Calcarenite Member of the Mississippian exposed in a tributary to the West Fork of the Ongoveyuk River (Loc. 4188). View is of units ONGO-W-12 to ONGO-W-19 (approximately).

Low altitude view of small falls developed in resistant cherty beds of lower member of the Mississippian exposed on tributary to the East Fork of the Ongoveyuk River (Loc. 4202). View is of units ONGO-E-TRIB 1 to 4 .

NIYR-3, poor exposure of badly slumped coal seam (above hammer) in Tertiary section exposed on West Shore of Niyrakpak Lagoon. 

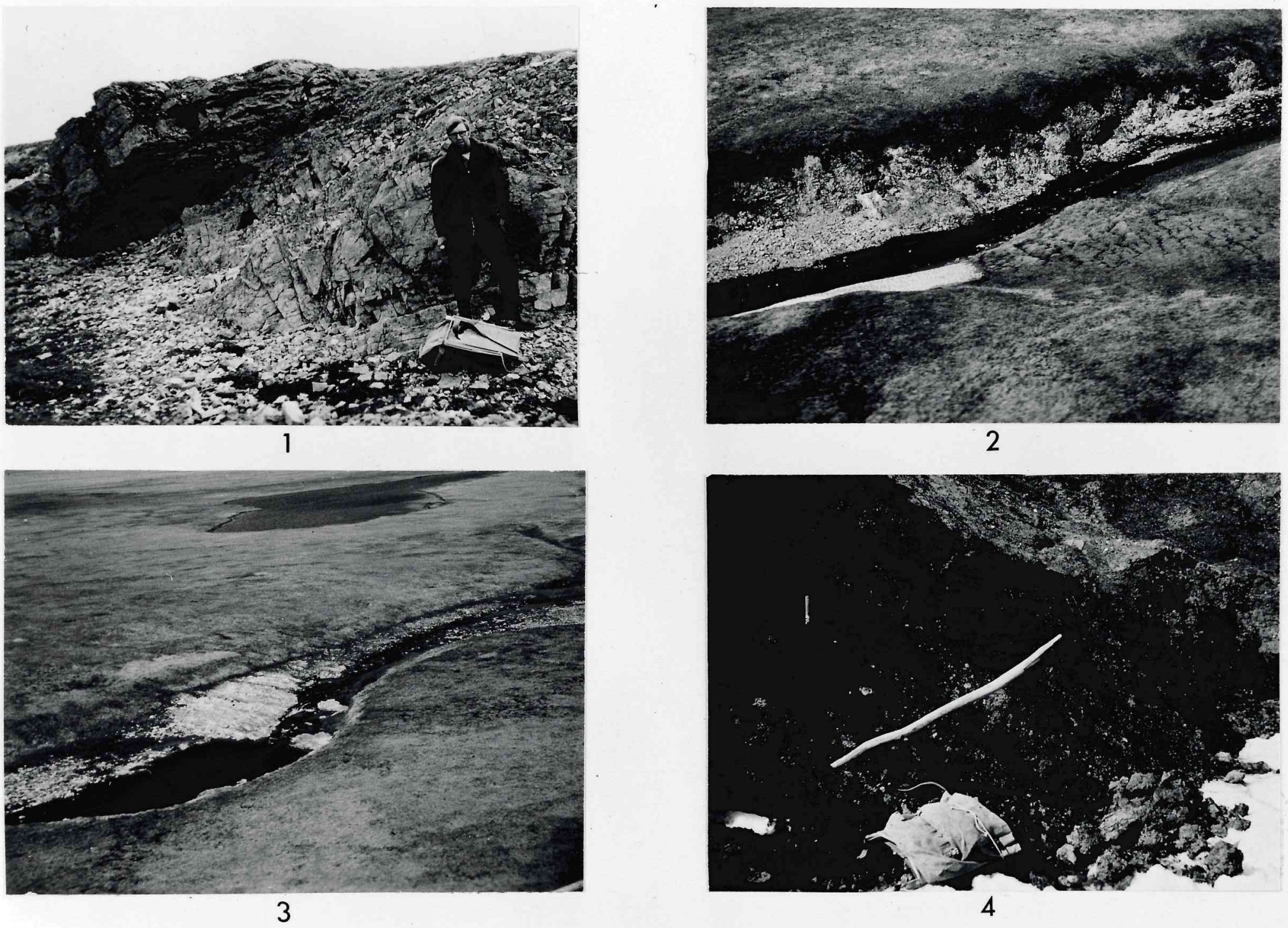